\title{
Analysis of Budget Shifts and Realization of School Finances During the Covid-19 Pandemic in Purworejo Regency in 2020
}

\author{
Rusmiyatun \\ Accounting Major \\ STIE Rajawali Purworejo Purworejo, Indonesia
}

rose.mia2691@gmail.com

\begin{abstract}
This study aims to analyze changes in the school financial budget and their realization after the Covid19 Pandemic in Purworejo Regency. School finances that are measured are the source of BOS funds from the central government and the PDPS funding source from the Purworejo Regency. The sample of this study was 477 elementary schools in Purworejo Regency. 477 samples spread over 16 districts in Purworejo Regency. This research is collaborating with the BOS Team for the Education, Youth and Sports Office of Purworejo Regency to measure compliance with the Budget Amendment regulations in accordance with the Regulation of the Minister of Education and Culture Number 19 of 2020. This research is a descriptive quantitative research. Researchers also get secondary data from school reports from the BOS Team in Education Office of Purworejo. The results of this study indicate a budget adjustment for handling covid19 in the education unit. The operational PDPS fund is reduced for each student by IDR 20,000. Funds for payment of teachers and honorary staff are reduced for the 3 month allocation, and schools change the source of funds by using the central BOS Fund. Central BOS Fund revenue does not change at IDR 900,000 per student, but its use changes, especially in the 2 nd and 3rd quarter of 2020 for spending on goods and services as well as for capital expenditure for covid19 handling activities in education units. The education unit in the realization of spending promotes transparency by posting reports on the use of funds on school display boards and reporting online on the website www.boskemdikbud.go.id. The ownership of special administrative personnel who handle school finances has a significant effect on reporting both offline and online.
\end{abstract}

Keywords: school budget, BOS fund, Covid19 budget, budget shift, school finances

\section{INTRODUCTION}

The Covid19 pandemic that emerged in 2019 hit all sectors. Its impact is felt by all walks of life. No exception in the field of education, the budget in the education sector during the Covid19 pandemic must be trimmed and diverted for covid response activities19. Activities of children who have to study at home through online media, and spending to increase school awareness in overcoming covid19 have caused a shift in the budget in the world of education. The education budget in Indonesia is one of the public budgets that has increased quite significantly in recent years. At least since the post-crisis period and is the largest sectoral expenditure compared to other sectors. The large amount of spending in this sector shows the government's commitment to prioritize education, apart from being motivated by the constitutional push to achieve a level of education spending of $20 \%$ of both the APBN and APBD expenditures. The education budget in schools is obtained from the School Operational Assistance (BOS) fund from the Central Government. This budget is directly transferred to the school account and used directly by the school. In addition to BOS funds, schools also receive school grants / School Financial Management Assistance Funds (PDPS) from the district government, and it does not rule out voluntary donations from students' parents, alumni and the business world.

A jargon of "Jer Basuki Mawa Beya" is very popular in the world of education, when we want glory, there must be a cost. Therefore, financing and budgets in the field of education are very much in the spotlight today. Especially in times of crisis because of the Covid19 pandemic.

According to Ahmad Arifi, education financing is one of the components of instrumental input which is very important in the implementation of education, especially in schools / madrasas). In every effort to achieve educational goals, both quantitative and qualitative goals, the cost of education has a very decisive role. There is almost no effort to ignore the role of costs, so that it can be said that without cost, the educational process (in schools / madrasahs) does not work. Cost in this sense has a broad scope, namely all types of administration relating to all types of implementation education, both in the form of money, goods and cashable labor). In this sense, for example, student contributions are clearly costs, but all physical facilities, both schools and teachers are also costs. Mulyasa emphasized that cost is one of the resources that directly supports the effectiveness and efficiency of education management. This will be even more pronounced in the implementation of school autonomy which demands the ability of schools to plan, carry out and evaluate as well as account for the management of funds in a transparent manner, both to the public and the government. In the provision of education, sources of funds are an integral part of the study of education management.

The role or obligation of the government in financing education is evident from the existence of the BOS / M program for School / Madrasah Operational Assistance), as described in the BOS Handbook, Financial Management and Monitoring and Evaluation. The book describes instructions for implementing School Operational Assistance, Financial Technical Instructions for School Operational Assistance, as well as Monitoring and Evaluation Technical Instructions. While community involvement, especially parents of students, in education financing, there is no legally binding minimum or maximum standard. Community involvement is 
more based on existing policies in the School Committee Education funding comes from various sources of funds, including APBN, APBD and donations from the community. Supervision in the field of education financial management is needed.

According to Sri Mulyani, Indonesian Finance Minister, through her Facebook page the Covid 19 pandemic prompted the government to roll out some assistance for the community in the field of education, for example internet quota assistance for students, teachers and lecturers. As for the achievements of the APBN output until October 2020 in the education sector, including construction of 528 primary / secondary school rehabilitation schools, construction of 24 dormitories and 25 study rooms in Islamic boarding schools, Smart Indonesia Program for 15.95 million students, School Operational Assistance for the Ministry of Religion for 7,6 million students, Bidik Misi / KIP Study for 736.72 thousand students, Ministry of Education and Culture Operational Assistance for 44.1 million students, teacher professional allowances for 838 thousand teachers, procurement of 42,915 educational equipment, procurement of 3,445 laboratory equipment, development 2,903 laboratories. The benefits of the education budget during the pandemic, among others, are focused on the Bidik Misi Scholarship / KIP College program, the Smart Indonesia Program where elementary school children receive 450 thousand aid per year. Teacher professional allowance and internet quota assistance. School Operational Assistance Funds must be planned and in the realization of the budget there must be accountable and transparent accountability. Nor Mubin (2018) states that the management of BOS funds at the school / madrasah level tends to be closed and does not follow the BOS fund management guidelines made by the Ministry of National Education. For example, it is the obligation for both the Dinas and schools to establish a Complaints unit. And announcing the School Income Expenditure Budget (APBS / M) on the school announcement board was apparently not followed by most schools. Of course, this is a note about the importance of monitoring the use of BOS funds at the school / madrasah level.

In Purworejo Regency, the most important source of funding for elementary schools is the Central BOS Fund, in addition to that there is School Aid from the Purworejo Regency government. This grant is used to finance 8 education standards. Schools must prepare a budget plan and budget realization. The covid19 pandemic has caused several budget items to be shifted. The technical guidelines for the management of the 2020 School Assistance Funds refer to the Regulation of the Minister of Education and Culture Number 8 of 2020, but the existence of Permendikbud Number 19 of 2020 concerning Changes to the Technical Guidelines for BOS as a result of the increased impact of the spread of Corona Virus Disease (Covid-19) on learning in educational units, requires schools to make a change budget to deal with the Covid Pandemic19.

Therefore, the Education, Youth and Sports Office of Purworejo district initiated this research to determine the Budget Shift in Primary Schools in Purworejo Regency and measure the level of school compliance in complying with Minister Education Regulation Number 19 of 2020 concerning Changes in BOS Technical Guidelines. Data on students at the primary education level in Purworejo Regency were recorded as 107,780 children. There are 507 public elementary schools in Purworejo Regency. Budget arrangement and realization of sources of education funds are crucial to be monitored and used as a monitoring and evaluation ground, so this research is needed.

\section{THEORY BASIS}

\section{A. Education Funding Policy}

Education Funding Policy is one of the decisions of public authorities in the context of the mandate of the Act. Education funding or funding has been regulated in the 1945 Constitution of the Republic of ndonesia Article 31 Paragraph 3 of IV amendments. The education funding policy can be referred to as part of State policy, namely as a product of the state whose policy is influenced and motivated by a political interest (Carnoy, 1982) or which we often refer to as Autonomy.

Autonomy according to Yoyon Bahtiar Irianto (2012: 73$74)$ is defined as self-government regulation (zelfwentgeving) or more accurately referred to as granting the right or power of self-government regulation to autonomous bodies. There is also a form of education autonomy in schools in the form of expanding school authority in managing funding and learning systems (Syakdiah, 2005). Along with the implementation of regional autonomy, the central government also began implementing a decentralized policy in education management.

Decentralization of education management implies that the delegation of authority from the government to the regions to make management decisions and develop their own plans in overcoming the problem of education, with reference to the national education system (Yoyon Bahtiar Irianto, 2012: 91).

The substance of decentralization in the management of education, includes aspects: (1) Educational legislation, (2) Organizational structure and educational institutions; (3) Development of educational curricula; (4) Professionalisation of education personnel; (5) Educational facilities and infrastructure; (6) Education Funding.

\section{B. School/Madrasah Financial Management}

School / madrasah financial management is all the efforts made by school / madrasah managers so that the financial and financing components are managed as well as possible, so that school / madrasah goals can be achieved effectively and efficiently, which includes; Investment Costs, Operational Costs, and Personal Costs. The duties of the financial manager are divided into three phases, namely;

a) Financial Planning, can also be called budgeting, which means the phase of coordination activities on all available resources to systematically achieve the desired goals

b) Implementation involves accounting (budget execution) means the implementation of activities based on a plan that has been made and allows adjustments to activities and budget if necessary.

Evaluation of the evaluation process must be carried out in every activity / program against budget achievement. Of the several phases of financial management,

According to Lilik Huriyah, there are several objectives in the financial management of education to be good, namely as follows; a. Increase the effectiveness and efficiency of the use of educational finance, b. Improve accountability and transparency of education finance, c. Minimizing abuse of 
authority and education budget. In order for the financial management of schools / madrasahs to be effective and efficient, the indicators are as follows: 1 . There is a planning process that is carried out by schools / madrasahs and then a school / madrasah revenue and expenditure budget is made. This school / madrasah revenue and expenditure budget is an activity plan for all madrasah stakeholders, so of course it must accommodate the interests of all school / madrasah residents. 2. There is a process of organizing and directing, which is carried out by the principal of the school / madrasah. This is important to do so that there is clarity for each madrasah member regarding the roles, duties, and responsibilities of each school / madrasah member who is assigned specific tasks in managing school / madrasah finances. 3. There is a process of implementing and then reporting, so that every school / madrasah activity is recorded with detailed financial revenues and expenditures. So that it will be clear the results achieved by the school / madrasah with the activities it carries out.

4. There is a process of supervision by the school / madrasah internally by the principal of the school / madrasah towards treasurers and activity implementers. As well as by external schools / madrasahs, for example supervision by the Inspectorate, BPKP, and BPK. The financial management framework for schools / madrasahs must include several things that must be considered, among others; record all receipts of school / madrasah funds, careful bookkeeping, accountability, exchange of expenses, ease of spending, financial policies in allocating appropriate funds. BOS Fund Management in Schools Based on Education Minister Number 8 of 2020 concerning Technical Guidelines for BOS Management in 2020, including:

The regular BOS Fund is managed by the school by applying the principles of school-based management, namely, the school's authority: to plan, manage, and supervise programs according to the conditions and needs of the school; planning refers to the results of school selfevaluation;

Schools have the authority to determine the use of regular BOS funds according to the priority needs of the school by taking into account the principles of regular BOS fund management; the use of regular BOS funds is only for the benefit of improving education services in schools and there is no intervention or deduction from any party;

The use of BOS Regular funds must be based on an agreement and joint decision between the BOS School team, teachers, and the School Committee. The result of the agreement above is written down in the form of minutes of the meeting and signed by the meeting participants. The agreement on the use of regular BOS funds must be based on the priority scale of the needs of the Education Unit, especially for the development of programs to improve the quality of learning for students in schools management of regular BOS funds in schools is carried out by the BOS School team; g. the

School BOS team is determined by the principal with the following membership composition: 1) the principal is the person in charge; 2) members consist of: a) treasurer; b) 1 (one) person from the teacher element; c) 1 (one) person from the 1 (one) person from the School Committee; and d) 1 (one) person from the parent / guardian element of students outside the School Committee who is elected by the school principal and the school committee by considering credibility and avoiding conflicts of interest;

h. management of regular BOS funds in open schools involves open school managers with the responsibility for the principal of the main school according to their level; $i$. the duties and responsibilities of the BOS School team are as follows:

filling in and updating school data completely and validly into Dapodik in accordance with the real conditions in the school; are absolutely responsible for the results of school data entry into Dapodik; compiling RKAS referring to the principles of effectiveness, efficiency, accountability, and transparency in the management of regular BOS funds; perform RKAS input on the system provided by the Ministry; comply with the requirements for effectiveness, efficiency, accountability and transparency in the management and use of BOS Regular funds;

6) complete accountability administration for the use of BOS Regular funds, as well as compile and submit reports on the use of Regular BOS funds in accordance with the provisions laws and regulations; confirm the funds have been received through the bos.kemdikbud.go.id page;

Some changes related to BOS Technical Guidelines due to the outbreak of the Covid19 pandemic, among others, are as stated in article 9A: Regulation of Education Minister Number 19 of 2020: "Power and service subscription financing can be used to purchase pulses, data packages, and / or paid online education services for educators and / or students in the context of implementing learning from home; and activity administration financing can be used to purchase hand sanitizing liquid or soap. disinfectant, mask or other hygiene support. ".

\section{RESEARCH METHOD}

The sample of this study was 477 elementary schools in Purworejo district, which are spread across 16 districts, namely Purworejo, Kutoarjo, Bayan, Grabag, Bener, Pituruh, Loano, Kaligesing, Purwodadi, Bagelen, Ngombol, Gebang, Need, Banyuurip, Kemiri districts. Research questionnaires were distributed through the Whatsapp Group of the Education, Youth and Sports Office of Purworejo Regency. The results of the data were processed using descriptive analysis. This study does not contain a hypothesis because it is to determine compliance and analysis of budget shifts from schools. Other secondary data were also obtained from the BOS Team of Purworejo Regency which came from the school expenditure reconciliation report to the Education, Youth and Sports Office of Purworejo Regency every quarter.

In addition, interviews with the Purworejo Regency Boss Team were also conducted to collect data. Methods of data collection techniques used three data collection techniques, namely: (1) in-depth interviews (in-depth interview), (2) observation, and (3) documentation studies. In this study data analysis was performed as recommended by Miles and Huberman (1992), and Mantja (1997), namely: (1) data reduction, (2) data presentation, and (3) conclusions.

\section{RESULT AND DISCUSSION}

\section{The Budgeting Process}

The budgeting process for Elementary School level in Purworejo District adheres to a participatory principle. The 
school invites relevant stakeholders to formulate programs and activities as well as budget details in one budget year. The amount of central BOS funds received per child is IDR 900,000, while the operational PDPS funds are IDR 20,000 per child in each school. Activities in school budgeting include:

1. Inviting school stakeholders, including school principals, teachers and education personnel, school committees and parents' representatives to formulate budget needs. There are some schools that also invite alumni or the business and industrial world.

2. Schools prepare school budget and income plans, in the preparation process, schools enter on two platforms, for the overall budget, schools enter online at the E-RAPBS Purworejo district via the rapbs.dindikporapwr.com page, each school enters the expenditure budget both from BOS funds Central and operational PDPS funds. Apart from that, especially for BOS, the school center concludes through the ARKAS application. So that schools enter one budgeting in 2 platforms.

3. Ratification of the budget in stages, at the initial stage of legalizing the education unit inviting parents of students to socialize and approval and endorsement

4. The approval of the sub-district coordinator level through the supervisor of each school.

5. After that it was validated at the Education, Youth and Sports Office of Purworejo Regency

6. After legalization, the school expenditure budget will be guided by the school to be used in spending guidelines.

From the research results, it turns out that there are differences in the parties involved in budgeting between one school and another. Not all schools involve parents of students in budgeting, only $67.9 \%$ of respondents involve parents as the formulator of the APBS

The school's financial sources come from the central BOS and PDPS funds, but there are 42 schools that get donations from parents of students, 4 schools get donations from alumni and 2 schools get donations from the business world. The allocation of central BOS and PDPS funds as well as other sources of funds are complementary.

There are 451 (94.5\%) elementary schools in Purworejo Regency do not have special administrative staff, so the staff who carry out the reporting of BOS funds are teachers who are given additional assignments. Meanwhile, 26 schools $(5.5 \%)$ have special administrative staff appointed to manage school finances. So that schools are more focused on reporting activities.

475 schools already know about the Ministry of Education and Culture regulation Number 19 of 2020 concerning BOS budget adjustments during the Covid19 period, but it turns out that there are still 2 schools that do not know about this regulation

The existence of this ministerial regulation requires schools to make a shift in the budget for funds used in schools and legalize them before use, but in fact there are still $10.2 \%$ or 52 schools that have not made their budget changes to date. This violates existing regulations stipulated by the Education Office and the BOS Center technical guidelines.

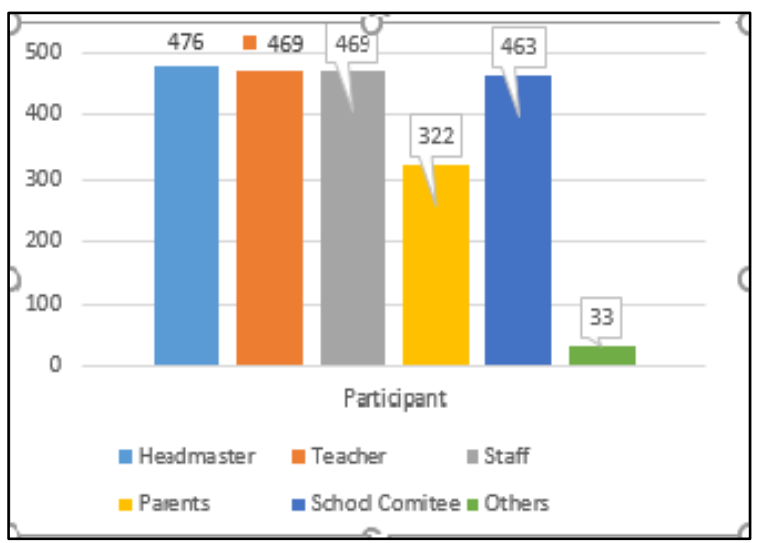

Fig. 1. Participants involved in compiling Budget in School

Shifts and changes to the budget plan are used by schools to shop for needs to anticipate Covid19, among others, capital expenditures for buying hand washing faucets, buying thermogun and shopping for goods including masks, faceshields, hand sanitizers, handwashes and others.

Receipt of the amount of Fixed BOS funds each student gets 900,000. The amount of PDPS Funds which initially each student was entitled to 20,000 became none at all, meaning that there was a reduction in the budget allocation for the education sector in Purworejo Regency. Each school decreased its income by 20,000 times the number of students

There is a reduction in other honorary teacher fees from PDPS funding sources, honorary teacher fees are not paid from the PDPS budget allocation for 3 months. The amount of teacher honoraria from the PDPS funds varies, starting from 500,000 to 700,000. so that the school made a revised budget to keep paying the honorarium for honorary teachers from other funding sources

In order to continue to pay the honorarium for honorary teachers, schools re-budgeted from other sources of funds. $469(98.3 \%)$ budgeted from the central BOS funding source, while 4 schools / $0.8 \%$ budgeted from parent donations and there were 2 schools that budgeted from central BOS funding sources and parents' assistance

The amount of expenditure for goods and services for Covid19 handlers increased in the third and fourth quarters, The amount of actual budget spent on average for each school was $10-20 \%$ of total funds received in the third and quarter. Meanwhile, investment spending for handling covid19 in the education unit reaches 5-6\%.

Planning and budgeting activities in schools must adhere to the principle of transparency and be notified to the community by posting a notification on a notice board. But apparently not all schools have made this announcement. There are still 32 schools / $6.7 \%$ that ignore this rule. Meanwhile, $93.3 \%$ of the other schools had followed the rules according to the technical guidelines for the use of BOS funds.

Transparency in reporting the realization of this expenditure must also be reported online through the channel www.boskemdikbud.go.id. All schools have set up this online reporting. The various demographic conditions in 
Purworejo Regency have caused some areas to have difficulty with internet signals. There are still $15.1 \%$ or 72 schools that have difficulty accessing the internet. This has led to the slow pace of required online reporting.

The ownership of special administrative personnel who manage school reporting also affects online reporting conducted by schools. Schools that have special administrative staff and good internet signals will more often access the www.boskemdikbud.go.id page. To do some reporting of school data, among others, checking the distribution of funds, confirming incoming funds, and reporting the use of central BOS funds

\section{CONCLUSION}

1. There are $10.2 \%$ of elementary schools in Purworejo Regency that have not made changes to their budgets, even though they have already spent on Covid19. So that the Education Office needs to re- socialize and tighten supervision to discipline schools to comply with the Minister of Education Regulation Number 19 concerning Adjustment of school budgets during the Covid19 pandemic.

2. There are $6.7 \%$ of schools that have not posted budget information and expenditure realization from the central BOS Fund. The Education Office needs to monitor and recommend compliance with this transparency to all primary schools.

3. There are $15.1 \%$ of schools that have difficulties with internet signals and this results in slow online reporting. The suggestion is that the Education Office needs to coordinate with the Ministry of Communication and Information for the provision of internet networks and ensure that the public can access them. So that school reporting continues to run well.

\section{REFERENCES}

[1] N. Mubin, "Integritas dan Akuntabilitas dalam Pengelolaan Keuangan Sekolah atau Madrasah," Attaqwa J. Ilmu Pendidik. Islam, vol. 14, no. 2 SE-Articles, pp. 80-92, 2018, doi: 10.5281/zenodo.3366740.

[2] M. G. F. Gain and I. V. Ancho, "Analyzing School Budget And National Achievement Test (NAT)," J. Penjaminan Mutu, vol. 5, no. 1 , p. 83, 2019, doi: 10.25078/jpm.v5i1.635.

[3] Y. Handayani, E. Pituringsih, and L. Handajani, "The Antecedents Implementation of School Operational Assistance (BOS) Funds and Its Consequences for Public Accountability," $E$ PROCEEDING STIE MANDALA Int. Conf. Call Pap. Good Corp. Gov. to Face Glob. Bus. Compet., pp. 2285-2308, 2017.

[4] K. J. Dougherty, S. M. Jones, H. Lahr, R. S. Natow, L. Pheatt, and V. Reddy, Performance Funding for Higher Education. 2016.

[5] T. Kinerja, K. Di, S. M. A. A. Krian, and I. Sulistyowati, "Pengaruh Rencana Dan Realisasi Penggunaan Dana Bos," vol. 16, no. 2 , pp. 146-157, 2019.

[6] J. E. Lopulalan, "ANALISIS PENGAWASAN PENGGUNAAN DANA BANTUAN OPERASIONAL SEKOLAH DI SD YPK EBENHAEZER LIMALAS KABUPATEN RAJA AMPAT," Jendela Ilmu, 2020, doi: 10.34124/ji.v1i1.51.
[7] L. W. Lee and H. M. Low, "The evolution of special education in Malaysia,” Br. J. Spec. Educ., 2014, doi: 10.1111/1467-8578.12048.

[8] MoF, "The Budget Statement and Economic policy," Minist. Financ., 2020. 